\title{
Keeping it pure - a pedagogical case study of teaching soft systems methodology in scenario and policy analysis
}

\author{
Ian Yeoman, Una McMahon-Beattie and Carol Wheatley
}

\author{
lan Yeoman is a Futurist at the \\ School of Management, \\ Victoria University of \\ Wellington, Wellington, \\ New Zealand. \\ Una McMahon-Beattie is the \\ Head of Department at the \\ Department of Hospitality and \\ Tourism, Ulster University, \\ Belfast, UK. \\ Carol Wheatley is based at the \\ School of Management, \\ Victoria University of \\ Wellington, Wellington, \\ New Zealand.
}

Received 7 December 2015

Revised 1 April 2016

13 May 2016

Accepted 13 May 2016

(c) Ian Yeoman, Una McMahon-

Beattie and Carol Wheatley.

Published in the Journal of

Tourism Futures. This article is

published under the Creative

Commons Attribution (CC BY 4.0)

licence. Anyone may reproduce,

distribute, translate and create

derivative works of this article

(for both commercial and

non-commercial purposes),

subject to full attribution to the

original publication and authors.

The full terms of this licence may

be seen at: http://

creativecommons.org/licences/by/

4.0/legalcode

\begin{abstract}
Purpose - Soft systems methodology (SSM) is well documented in the academic and management literature. Over the last 40 years, the methodology has come to be adapted depending on the tool users' skills and experience in order to fit the problem. The purpose of this paper is to demonstrate good teaching and learning practice from a pedagogical perspective.

Design/methodology/approach - Dr lan Yeoman of Victoria University of Wellington provides a personal reflection of how the methodology is used in the teaching and learning of TOUR301 Tourism Policy and Planning as a policy and scenario analysis method.

Findings - The paper articulates the seven stages of SSM from problem situation unstructured, through to Rich Pictures, vision and guiding principles, policy solutions, comparisons, feasibility and implementation stages. The paper uses a series of teaching tasks to breakdown the complexity of the methodology thus guiding students and teachers in how to deploy the methodology in the classroom.

Originality/value - The value of the paper demonstrates the reflective practice of SSM in action as an exemplar of good practice. The paper clearly articulates the stages of the methodology so students and teachers can adopt this approach in classroom environments following a scaffolding learning approach. The use of teaching tasks throughout the paper helps bring clarity and order thus enabling the teacher to effectively teach the subject and the students to learn. The most significant contribution of this paper is the articulation of good teaching practice in policy and scenario analysis which articulated through four learning lessons: facilitating a learning environment; the impact of visual thinking; political theory; the importance of incremental learning; and problem-based learning and international students.
\end{abstract}

Keywords Tourism, Policy, Pedagogy, Scenario analysis, Futures, Soft systems methodology

Paper type Research paper

\section{Introduction}

Soft systems methodology (SSM) (Checkland, 1981) is well documented in the academic and management literature ever since the birth of the process by Professor Peter Checkland in 1981 in the ground breaking book Systems Thinking: Systems Practice. The process or methodology was developed as a problem-solving strategy for those faced with resolving highly complex and inter-related problem situations. Over the years, the methodology has come to be adapted depending on the tool users' skills and experience in order to fit the problem thus, SSM, has become known as a problem framing device or recipe in which the principles are followed and adapted in order to achieve an outcome (Mingers, 2000; Yeoman, 2004a, b). Peter Checkland acknowledges this development is a move away from the step by step approach to more of a 
flexible rendition published in Soft Systems in Action (Checkland and Scholes, 1990). Today, SSM has been widely disseminated and applied in many geographical contexts and academic disciplines (Mingers, 2000). This paper is fundamentally a personal perspective of how Dr lan Yeoman uses SSM as a scenario analysis tool in the teaching of TOUR301 Tourism Policy and Planning (which will be referred to as TOUR301) at Victoria University of Wellington. My motivation for the paper comes out of students wanting clearer examples and direction of how I have adapted the methodology for teaching and why.

This is my personal story. I am a graduate of Sheffield City Polytechnic with a BSc (HONS) catering systems. The core of the degree was a systems thinking approach to student learning of which SSM was a core dimension. Too be honest, I really never understood the process. The methodology at the time was too conceptual and those that taught the courses delivered the subject in a rather abstract and mechanised way keeping to the principles and rigidity of the methodology of the time (Mingers, 2000). Whereas today, SSM embellishes the adaptive and reflective process as a problem structuring methodology that guides students understanding of a problem situation in order to make sense of the problem, generate solutions, evaluate options and implementation (Mingers, 2000; Yeoman, 2004a, b). Basically, using the process to fit the problem and learning situation [...] and keeping it simple.

\section{TOUR301}

TOUR301 is a third year course as part of the Bachelor of Tourism Management degree. The course aims to help students develop the skills and knowledge necessary to understand and critically analyse tourism public policy, planning and processes within New Zealand and a wider context. The theoretical and applied emphasis is on developed countries with advanced democracies, thus allowing the student to observe and understand examples of best practice and good governance. The course consists of lectures and tutorials that are delivered in a logical sequence in order that the student can grasp the basics of policy and planning in context. The central theme running through the course, from a pedagogical perspective it is about developing student's skills in applying policy and planning frameworks, hence the paper uses scenario planning and SSM as envisioning and analysis tools. Given the location of Victoria University of Wellington as New Zealand's capital city, a number of guest speakers from government departments, industry associations and local government discuss the key issues and challenges in tourism policy and planning. TOUR301 objectives and graduate attributes are listed in Table I.

The assessment focusses on students developing strategic plans from a public policy perspective. This involves considering the elements of trends, political theory, stakeholder analysis, risk management, implementation, value systems and measurement. Industry leaders and stakeholders participate throughout the paper through a series of lectures called "What future could it be?" Fundamentally, outlining their vision(s) of the future, identifying risks, stakeholder values and strategic actions. For the purposes of this paper, I (lan Yeoman) demonstrate how I teach SSM as a scenario analysis tool for case study learning.

Table I Objectives and attributes

Course objectives

1. Provide a systemic examination of tourism planning and policy making within a range of contexts and strategies drawing upon examples from New Zealand and the wider world

2. Apply theoretical concepts to practical applications through an in-depth examination of tourism planning development and policy making

3. Assess policies and planning strategies using multiple futures environments and policy analysis tools
Graduate attributes

Critical thinking: through critical thinking, develop the ability to systemically analyse policy relationships.

Communication: conveyance and synergy of complex issues through written and oral mediums

Critical thinking: simulation of real time problems through case study examination in a pressurised/limited time frame

Leadership: role play in the context of policy and planning through management case studies

Critical thinking: using reflective and creative thinking styles, evaluation of multiple futures using comparative commentary

Communication: communicate complex ideas coherently, appropriately and rationally 


\section{What is SSM?}

SSM (Checkland, 1981; Checkland and Scholes, 1990) is a methodology for dealing with complex, unstructured problematic situations developed by Professor Peter Checkland at Lancaster University. SSM evolved in response to the failure of systems analysis to address messy and complex problems, those problems about human activity. Systems analysis was a paradigm of hard systems where a model has precise objectives and can be expressed in quantitative terms allowing the development of mathematical models. According to Kirk (1995, p. 14):

These models can be used to predict the response of the system to changes in the environment. The model produces a convergent solutions to any change. The model can be expressed in the form of a mathematical equation with a precise measure of outputs - a deterministic model. Where there is more uncertainty, the relationships may be expressed in the terms of probability of output as a response to a change in inputs - stochastic models. Also, this can be extended to include non-continuous relationships through the use of chaos theory.

Checkland arrives at Lancaster University in 1969 in the newly formed Department of Systems Engineering, clearly knowing what he wanted to achieve:

His inaugural lecture foreshadows the major themes of soft systems thinking. He saw the task to take conventional, hard, systems engineering and through practical engagements, develop it to be able deal with the humanness of human beings and, in particular highlighted the importance of irrationality, creativity and values of which went unrecognized with systems engineering (Mingers, 2000, p. 738).

Checkland's approach involves delving into the human activity of problems and decision making rather than a hard systems or classic operations research approach. SSM thus explores the social and political dimensions of the problems remembering that:

[...] every human problem situation is the product of a history, one which will dictate perceptions, judgements and standards (Hicks, 1994, p. 228).

SSM is often used by consultants as a means to structure problems, but understanding this intervention is about human behaviour and actions. Humans are not mechanical; their behaviour is shaped by risk, motivations and attitudes. As a problem structuring methodology (Yeoman, 2004a, b) and intervention process, SSM involves the careful observation of the problem situation, the recording of those observations, the gathering of facts and opinions usually in a qualitative manner. Here, users are gathering human activity systems as brief descriptions and expressed in the form of a cartoon style diagram. This cartoon diagram is enriched with further facts and opinions, thus becoming "rich" and known as a Rich Picture. Opinions of stakeholders are of particular importance in understanding the political behavioural defensive and supportive messages. Solutions or options are modelled to see how they would change the Rich Picture and for reaction from stakeholders. An appropriate solution is selected for implementation that considers culture and feasibility and concluding with actions to improve the problem situation. Figure 1 represents the adaptive model process of SSM as used in TOUR301.

As Hicks (1994) points out SSM is intended to be a flexible and evolving problem solving methodology that is adapted and modified based upon the tool users' experience and the problem situation setting. Although Figure 1 represents the classic seven stages of SSM, projects do not necessarily start at Stage 1, problem situation unstructured, but works maybe carried out concurrently. Tool users may return to earlier stages and repeat various steps. As Mingers (2000, p. 740) notes:

Checkland found that they rarely used it following the rigidly of the seven-stage methodology and so a more generalized and flexible representation of the process was developed.

\section{Using SSM as scenario analysis tool in the context of policy and planning}

Scenario planning is a research technique that has evolved into business sectors from the early 1960s subsequently acquiring increasing academic provenance and practical success by assisting businesses to prepare not simply for one "official future" but a range of possible futures. In the postmodern era which is characterised by uncertainty and contingency, increasingly scenario thinking and planning are being used in the public and private sectors (Yeoman, 2004a, b). 


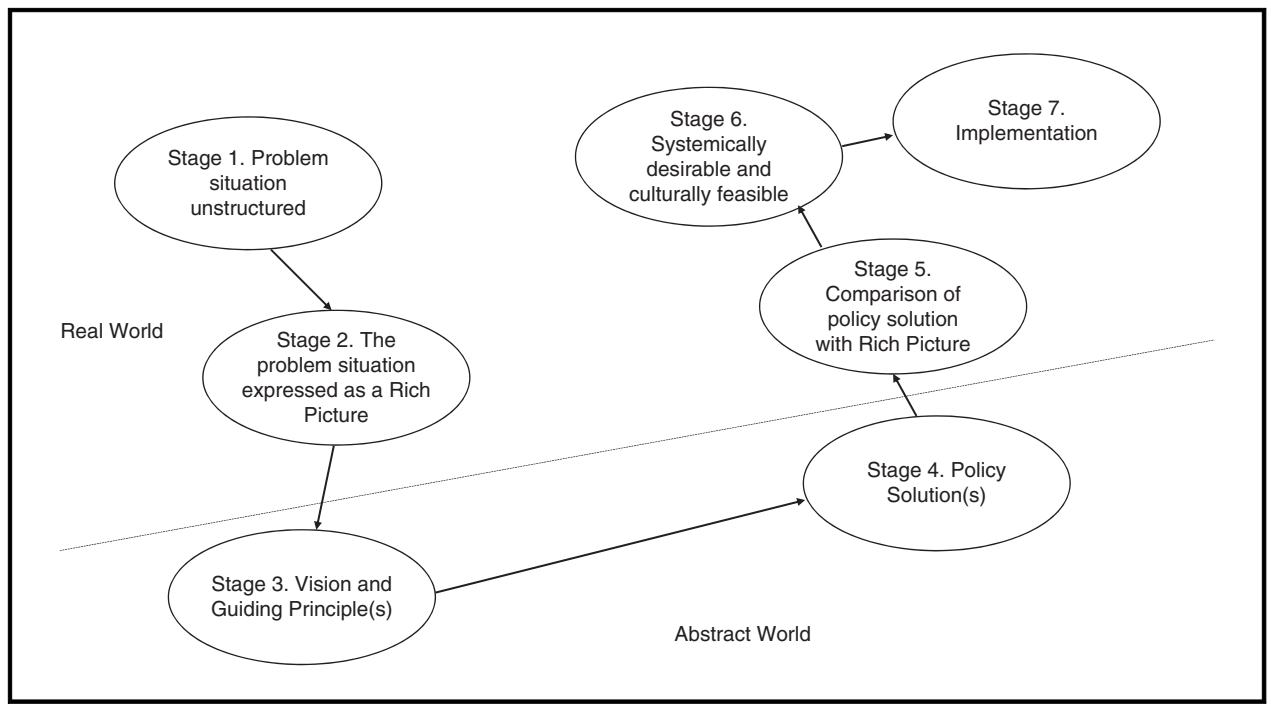

Facilitating strategic conversations of diverse stakeholders and embracing the complexity of their multiple perspectives, scenario planning promotes a broader action focussed perspective. I have authored a number of papers and studies that have followed Shell's (van der Heijden et al., 2002) approach to scenario planning which follows a multiple futures perspective in which four pictures or scenarios of the future are constructed in order to enable stakeholders or participants to think about future events or circumstances. In the tourism industry, studies have included country studies such as New Zealand (Yeoman and McMahon-Beattie, 2014) and Scotland (Yeoman, 2004a, b) or specific sectors such as ecotourism (Yeoman et al., 2014) and festivals (Robertson and Yeoman, 2014) or specific circumstances including oil (Yeoman et al., 2006) or foot and mouth disease (Yeoman et al., 2005). Scenario planning is a process of construction where the future is presented as pictures, states or stories. Whereas scenario analysis is how your company, country or organisation would respond to that future scenario. SSM is used in TOUR301 in the context of scenario analysis.

From a tourism perspective, policy making is characterised as a dynamic socially constructed activity that involves a wide range of agents and organisations with a wide variety of interests and commitment to tourism (Dredge and Jenkins, 2006). A tourism policy perspective from a systems approach recognises that interactions occur between actors and the institutional and environmental frameworks, thus acknowledging that policy development is both internal and external in which stakeholders and actors do not exist in isolation but impact on each other. Adopting a systems approach in tourism planning, and an understanding of these relationships produces a holistic view.

SSM, policy making and scenario analysis overlap. The SSM process (Figure 1) is very similar to the classic policy cycle (Figure 2). The policy process is a complex, multi-layered process involving many institutions and actors, thus it is a process that is mediated, and appropriate actions and interventions identified (Dredge and Jenkins, 2006). Therefore, the policy process mirrors the attributes of the SSM as a human activity system in capturing political actions and values that Checkland (1981) portrays. The policy cycle, like SSM is grounded in engagement with stakeholders and communities of interest. Both deal with issues, position a viewpoint, capture stakeholder values, actions and beliefs, generate solutions, evaluate solutions and deploy implementation and change management programmes.

Thus SSM and the policy cycle:

- is a process or series of stages or decision points that shape the nature and outcomes of succeeding stages;

- the formulation is geared towards actions and decision making; 


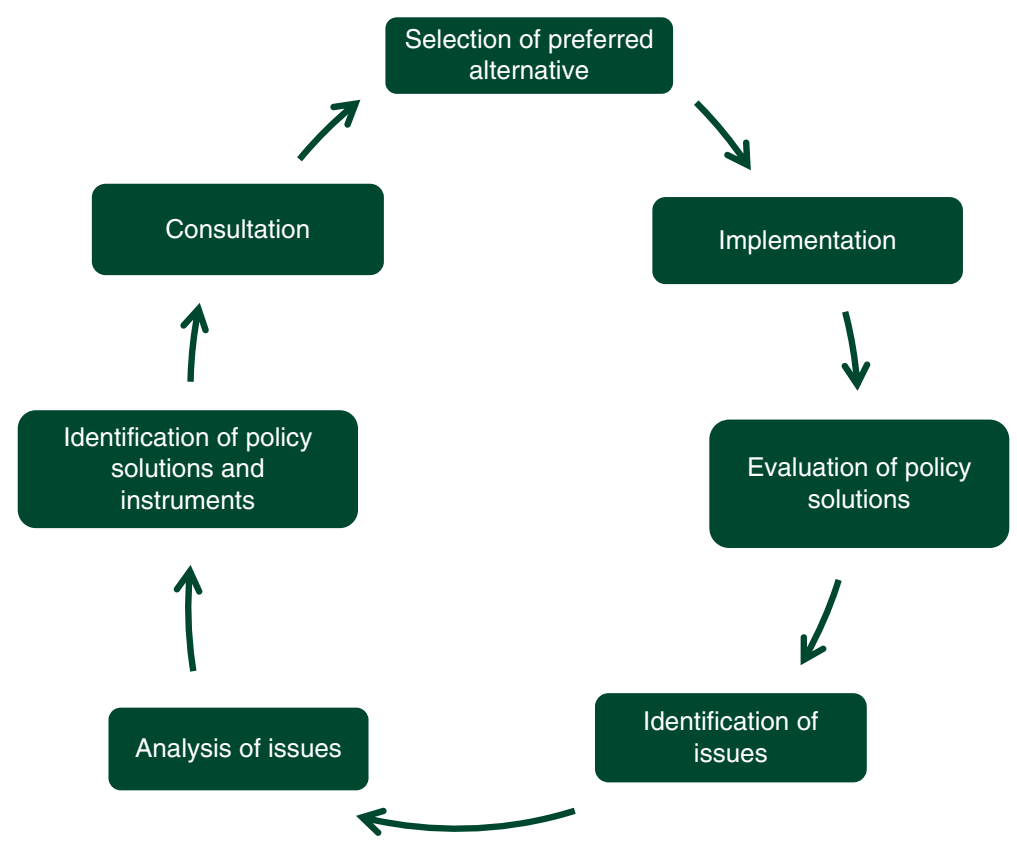

Source: Dredge and Jenkins (2006)

- identifies issues and ways to manage them; and

- is a socio-political construction shaped around values and beliefs.

Scenario analysis and policy analysis is determining which of various alternative policies will achieve a given set of goals in light of the relations between policies and goals. SSM uses conceptual models as policy options and through examining the degree of change that conceptual models bring to a Rich Picture an evaluation can be made of a policy intervention. Different conceptual models can be viewed as scenarios in order to judge difference. These conceptual frameworks are often founded on political theory perspectives, that is, capitalism, neo-liberalism or social democracy in the teaching of TOUR301. Checkland uses the term weltanschauung, which is generally translated to mean viewpoint, thus weltanschauung is replaced with political position in the shaping of solutions, policy options or conceptual models.

Figure 1 is an adaptation of SSM with the following changes:

- Stage 3: the root definition is renamed vision and guiding principle(s).

- Stage 4: the conceptual model is renamed policy solution(s).

- Stage 5a: formal systems model is not used.

- Stage 5b: other systems' thinking is not used.

\section{SSM intervention}

In order to illustrate the process of SSM in the teaching of TOUR301 a case study "New Zealand: is it an Eco Paradise?" is deployed (see the Appendix). As noted previously, SSM is like a flexible process that has been adapted and is presented in the way I use the process. I remind my students that SSM is like baking a chocolate cake, we use a recipe as a guide but we change and adapt that recipe. We all have different recipes for chocolate cakes, some gluten free, others with no eggs or with premium chocolate. From a theoretical perspective, SSM is associated with tool use theory where the tool is adapted and altered by the tool user (Yeoman, 2004a, b). Hence the presentation of SSM in this paper is based upon feedback over the years from students and my personal learning. 


\section{Stage 1: the problem situation unstructured}

The problem situation unstructured is the beginning of the process or the entering stage of the problem situation in which students as consultants would be negotiating the problem, setting boundaries and forming relationships. Here, it is understanding the project (or assignment brief), evaluating political power, identifying who is the problem owner and social aspects, introductions to stakeholders and actors, gathering forms of data and undertaking secondary research. At this stage, I say to students "what do you think the problem is" and "formulating terms of reference". "New Zealand: is it an Eco Paradise?" is a case study of the a situation of tourism in New Zealand which addresses the question "Is New Zealand an ecotourism destination?". The question, from a SSM perspective assumes a degree of ambiguity or a messy problem. The teaching task at this stage describes the project brief, tasks and outcomes. At the end of Stage 1, the students should be familiar with New Zealand tourism, have undertaken a literature review of its present state and identified the key stakeholders' actors (Table II).

\section{Stage 2: the problem situation expressed as a Rich Picture}

Once necessary data have been gathered to identify the key facts, issues and stakeholders; the situation is constructed using a carton style diagram called a Rich Picture. A Rich Picture according to Hicks (1994) is used because:

- a picture can show far more information in the same place;

- it shows patterns, arrangements, connections and relationships;

- it provides a holistic overview;

- less likely to overlook vital links and interactions which may have given rise to unexpected or intentional consequences;

- it permits a feel for the problem and issues; and

- it provides a representation that can be instantly shared with others.

Rich Pictures were developed as a means of presenting complex situations or messy situations. The idea of using Rich Pictures is common in several problem solving or creative thinking methods because our intuitive consciousness communicates more easily with impressions and symbols rather than words (Open University, 2014). Cartoon style drawings evoke and record insight into a situation thus providing a holistic and unstructured (or structured) representation.

\section{Table II Teaching task: the policy brief}

You (students) have been employed by the New Zealand Ministry of Economic Development to evaluate the countries national brand and tourism strategy. There have been recent stories in the international press about how stakeholders are concerned regarding the country's 100\% Pure New Zealand image. This has become a political issue with questions about the strategy direction of tourism being raised in Parliament by the political opposition. The Rt. Honourable John Key as Prime Minister and Minister of Tourism has commissioned this study as a response to the issues seeking an evaluation of the present state and policy options for the future. Consultants (student groups) will use SSM as there investigative methodology

Questions

Who are the problem owners?

Who are the key stakeholders in New Zealand tourism?

What are the issues?

What are the tasks to be completed?

Sources of information and stakeholders for investigation include

Auckland Tourism Events and Economic Development (www.aucklandnz.com/ateed)

Department of Conservation (www.doc.govt.nz/)

Ministry of Economic Development (Tourism) (www.med.govt.nz/sectors-industries/tourism)

New Zealand Airports Association (www.nzairports.co.nz/)

Regional Tourism Organisations of New Zealand (www.rtonz.org.nz/main.html)

Statistics New Zealand (Tourism) (www.stats.govt.nz/browse_for_stats/industry_sectors/Tourism.aspx)

Tourism 2025 (http://tourism2025.org.nz/)

Tourism Export Council of New Zealand (www.tourismexportcouncil.org.nz/)

Tourism Industry Association of New Zealand (www.tianz.org.nz/)

Tourism New Zealand (Corporate) (www.tourismnewzealand.com/)

Tourism New Zealand (Visitor) (www.newzealand.com/) 
They are an attempt to encapsulate the real situation in a summary format that is accessible and understood by others. A Rich Picture does not have to be a work of art as long as it makes sense.

The symbols in Figure 3 are a useful reference for the students in order to help them get started (Table III).

How do you know when you have finished a Rich Picture? The picture will never be completely finished as representing all of the information that has been gathered is not an infinite activity. Students see different things in different situations and will bring different interpretations from the case study. Thus it makes it difficult to say "when is the end". Rich Pictures are revisited at the comparison Stage 5 when Rich Pictures and policy solutions are redrawn. Any inadequacies resulting in a misinterpretation will surface, but this is why SSM is a process of iteration rather a defined recipe.

From Figure 4, the Rich Picture could represent the following key issues from the case study "New Zealand: is it an Eco Paradise?":

- The economic and political importance of tourism in New Zealand economy, whether it is jobs or John Key as Minister of Tourism leading to the development of a 2,025 national framework.

- " $100 \%$ Pure New Zealand" campaign is considered to be a "natural extension and elegant expression of the New Zealand's tourism product. The brand is the world's longest running campaign and most successful. Is the brand 100\% Pure true given negative media stories, polluted rivers and endangered species?

- The main reason for visitation are the natural attractions and environment, this has been the case historically and is today.

- New Zealand, tourism is a key contributor to the country's economy representing 3.7 per cent of GDP and 4.9 per cent of jobs.

- The decline of visitors from traditional markets such as the UK and Europe.

- Climate change is changing tourism products and experiences.

- The emergence of new markets and tourists from India and China.

- The value of the New Zealand dollar, geographical location, price of oil and increased competition from other destinations make the economic environment challenging.

\section{Figure 3 Some symbols for the use in Rich Pictures}

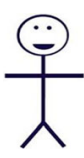

Person

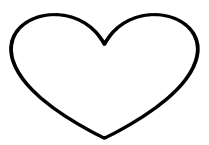

Close relationship

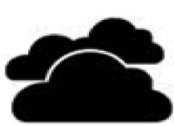

Under a cloud

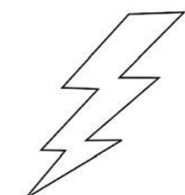

Act of God

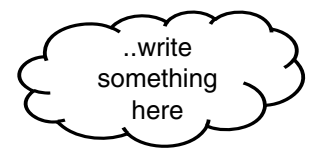

Commentary bubble

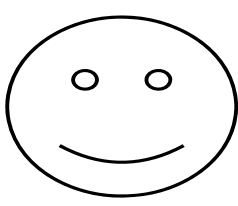

Happy

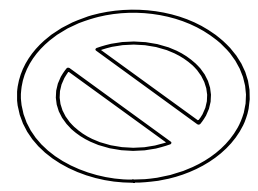

Forbidden

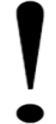

Source of concern

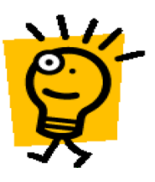

Idea

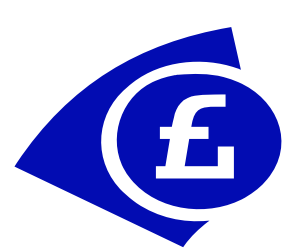

Money 
I have learned that students can deal with writing reports and are comfortable with rational approaches to problem solving. SSM is different, it is an abstract. At the core of the SSM process is the use of Rich Pictures. A cartoon style diagram which asks the students to draw the problem rather than write about it. So it is different. The challenge is getting students started and guiding them through the process of constructing a Rich Picture For this, students need the following materials

Soft pencils

Rubbers

Pencil sharpener

A3 paper

Clour pencils

In order to prepare a tutorial in which the students represent the case study in the form of a Rich Picture they should in advance

Identify 10 core issues (whether positive or negative) from the case study, making notes of the page and paragraph number from the case study

For the tutorial activity

Let the students work as individuals. Use an A3 blank piece of paper; place the 10 core issues onto the paper in the form of cartoon symbols (see symbols from Figure 3)

Subsequently, for each paragraph in the case student identify further issues and add to the Rich Picture. Thus the students are enriching the Rich Picture

Ask the students to connect cartoon symbols with flow arrows

If the students are having difficulty using cartoon symbols they may use bubble clouds with commentary to represent issues, aspects or situations At this stage it also advisable to ask students to share and comment on their Rich Picture

Students often comment that "they are not Picasso or Michelangelo" therefore "how do you assess my Rich Picture". My reply is often "that is right, I am not assessing your artistic ability but how you have portrayed and identified the key issues from the case study". One way to do this is the use of picture key. In order to do this, I advise students to

Once you are happy with your Rich Picture, identify the top ten issues and number these issues 1 through to 10 on the Rich Picture Construct a table at the side of the Rich Picture that corresponds to the numbers you have identified and then rank the issues in order of importance, the page and paragraph number from the case study, an explanation of the issue and why it is an issue

My doing the above, the students critically appraise and communicate the essence of the problem

To bring the Rich Picture to a conclusion, I use the question "summarise in not more than 40 words 'what the central issue or problem in the case study is?"”

Figure 4 Rich Picture for "New Zealand: is it an Eco Paradise"

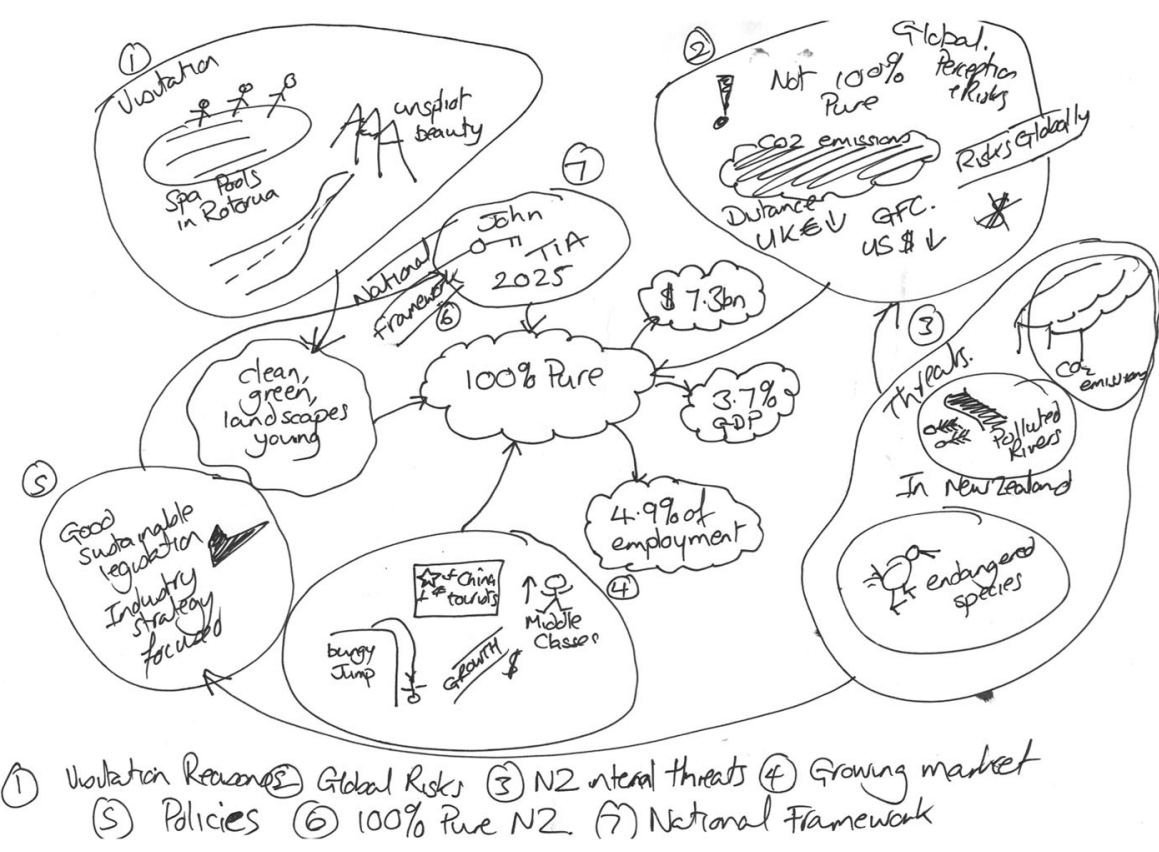


Checkland (1981) argues that Rich Pictures identify a number of key issues of concern, whereas I define issues as positive or negative, otherwise the Rich Pictures just draws on negative issues resulting in an uneven balance. In order to bring this section to a close and provide students with summative statement of the situation, I get the students identify the central issue which is a combination of issues they have already listed in no more than 40 words. From "New Zealand: is it an Eco Paradise?" the central statement could be:

A changing macro environment will bring about change to the future of New Zealand tourism whether this is climate change, shifting markets or destination brand. Thus, New Zealand tourism needs to decide what it wants to be and how it can achieve that future?

\section{Stage 3: vision and guiding principle(s)}

At this stage, the root definition is renamed vision and guided principle(s). A root definition is a crucial stage of SSM, as it is a concise verbal description of the system that students are trying to model when compared to the real world problem situation resulting in change. The real world situation is the Rich Picture. Root definitions need to be worded carefully because the conceptual model that is built at the next stage reflects the root definition. Hicks (1994, p. 244) believes that the following elements should be found explicitly in well-formed root definitions.

Transformation process - the means by which the defined inputs to our system are transformed into its outputs.

Ownership of the system - some agency that has prime concern for the system and which has the ultimate power to cause the system to cease to exist.

Customers - the people within or outside the system who will be the beneficiaries or victims of the effects of the systems activities.

Environment constraints - features of the systems environment (including wider systems of which our system is a component) which have to taken as given.

Worldview (weltanschaung) - the standpoint from which we have chosen to view the system. Because of its nature is not usually explicitly stated in the Root Definition.

For the teaching of TOUR301, the root definition becomes the vision and guiding principle for a policy direction or strategy because of simplicity. Students find it difficult to grasp the concept of weltanschaung. But using the stage as the foundation (hence root definition) of a policy solution allows the students to build the conceptual model or policy solution at the next stage.

Visioning suggests the active occupation of looking ahead rather than merely looking at or analysing something. It is a state which we want to be, a goal, a direction. A vision is something we aspire to that will drive us to seek something new. Thus a vision is a picture of the future of where "l" want to be or a picture of the future of what "I" want us to be or a picture of the future of where we should be (Yeoman et al., 2014). Whereas, a guiding principle is how you behave in order to achieve a vision. Guiding principles are based on the notion of a principle of law or rule that has to be, or usually is to be followed, or can be desirably followed, or is an inevitable consequence of something, such as the laws observed in nature or the way that a system is constructed. The principles of such a system are understood by its users as the essential characteristics of the system, or reflecting system's designed purpose, and the effective operation or use of which would be impossible if any one of the principles was to be ignored (Kakabadse, 2005). Thus guided principles are the principles or precepts that guide an organisation throughout its life in all circumstances, irrespective of changes in its goals, strategies, type of work or the top management. In the case of teaching TOUR301, these are the philosophies that underpin political behaviour, for example, socialism, capitalism or environmentalism. If socialism is accepted, the guiding principles relates to the development of a social and economic systems characterised by the social ownership of the means of production and co-operative management of the economy (Heywood, 2013) (Table M).

\section{Stage 4: policy solution(s)}

This stage of SSM is reworded from conceptual models to policy solutions. According to Checkland (1981) building a conceptual framework in SSM is to construct a model of a potential solution. 
Hicks (1994) establishes the root definition as a mechanism to guide the construction of a solution, a direction in which to build a conceptual model. Here, we treat the root definition as a vision of a potential solution to address the issues in the Rich Picture. An example for the case study "New Zealand: is it an Eco Paradise?" is

Vision: to be New Zealand's First and Everlasting Industry

Vision explained: to be New Zealand's first industry in the terms of economic, career choice and aspiration whereas everlasting preludes to those that have responsibility for tourism today act as guardians for future generations

Guiding principles: for the common good through balancing for the future

It is suggested students construct two opposing visions and guiding principles based upon opposite or different political ideologies, thus allowing the students to learn different policy perspectives

His conceptual model is represented as a bubble diagram (see Figure 5) which are decisions of a policy option constructed around the root definition that address the issues in the Rich Picture. Hicks (1994) believes that a conceptual model describes activities of human activity systems, and so activities are the entities which form the components of the conceptual framework. The root definition determines the activities of the conceptual framework, hence the renaming as vision and guiding principle.

Pearce (2012) broadly states that conceptual frameworks identify and bind knowledge and form a framework to help researchers understand a particular phenomenon and thus make explanatory claims. Essentially, conceptual frameworks are concepts explained in diagrammatical form and indicating relationships through connections. In TOUR301, the

Figure 5 Conceptual model or policy solution for "New Zealand: is it an Eco Paradise?"

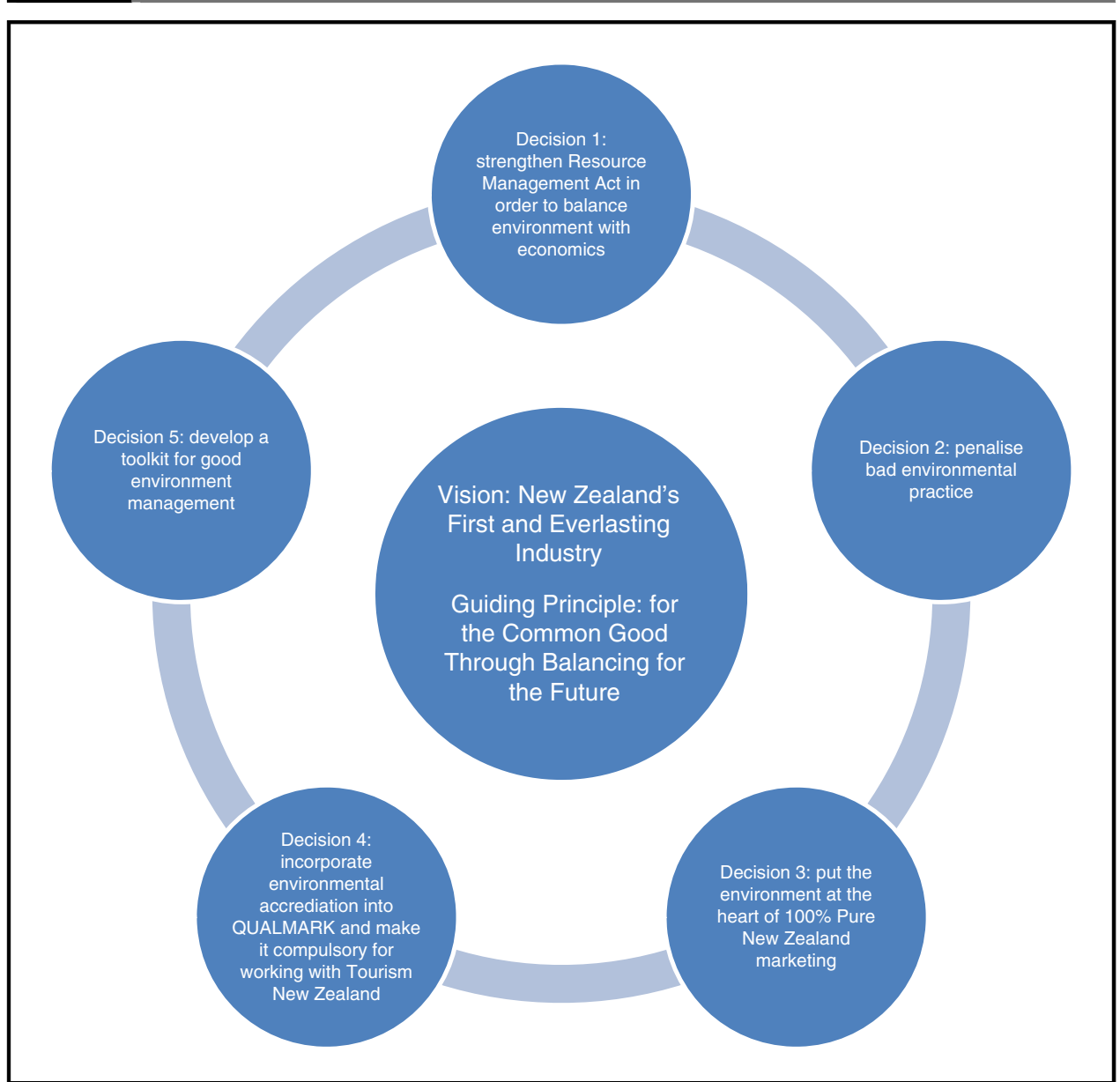


conceptual frameworks are policies. These are the decisions that address the issues in the Rich Picture. In Figure 5, policy solution that contributes towards the vision underpinned by the guiding principle and consists of five decisions. These decisions consist of policy instruments (Dredge and Jenkins, 2006). Policy instruments are the means by which governments agencies achieve their end goals. These agencies confront problems using a range of instruments, programs, tools, approaches and techniques. All instruments have strengths and weaknesses. The choice of instrument(s) depends on the type of problem, availability of resources, political commitment, government priorities and level of government to name but a few. These instruments are also based upon political value systems. For example, a socialist system advocates state intervention into the production system of tourism using legislation to control the means of production, whereas neo-liberalism advocates the private sector and thus a legislative framework of light regulation to encourage profit and business.

In Table V, Dredge and Jenkins (2006, p. 161) group policy instruments into the following categories.

As TOUR301 adopts a political perspective, the level of government involvement in tourism is considered. For example, a socialist ideology is about government control of the system and bureaucratic structures whereas a neo-liberal ideology connects to market forces. Dredge and Jenkins (2006) conceptualise policy instruments based upon a continuum of government control. A neo-liberal use of voluntary instruments are characterised by low levels of government involvement

Table V A selection of policy instruments in tourism

Form of policy instrument

Advocacy: using information and education to manipulate behaviour

Money: using financial incentives, spending and taxing

Government action: delivering services directly or indirectly facilitating their delivery

Law: legislation, regulation and compulsory provisions to achieve compliance
Examples in tourism

Strategic tourism plans (with no statutory base)

Ecotourism guidelines

Accreditation schemes

Demonstration projects

Environmental management

Encouragement of international investment

Tourist levies

Departure taxes

Accommodation levies

User pay charges

Licenses and permits

Differential charges for tourists

Developer contributions

Tax rebates

Investment incentives

Tax rebates

Loan guarantees

Tax relief

Direct and indirect subsidies

Fines

Penalties

Declaration of free trade and investment zones

Infrastructure provision

Resort development

Provision and management of attractions and services, such as hotels and museums.

Interpretation facilities

Marketing and promotion

Education

Research

Zoning

Land use regulation

Building regulations

Public health and occupational health and safety

Fire and safety regulation

Foreign investment regulations 
and low dependency of government resources whereas a socialist policy instrument requires high levels of government involvement, control and resources (see Figure 6 for examples) (Table VI).

\section{Stage 5: comparison of Rich Pictures and policy solution(s)}

The purpose of stage five is to evaluate the impact of the conceptual model or policy solution impact on the Rich Picture or problem situation. Evaluation is defined as the disciplined and critical assessment of the consequences of government policy and actions (Dredge and Jenkins, 2006). This evolves the evaluation of the issues and problem using a range of quantitative and/or qualitative methods. The process requires policy analysts to have both creative and analytic skills. Stage 5, does not evaluate against risk or stakeholder values as the evaluation is based on the "best business case" rather political risk or stakeholder values. In Stage 6, cultural feasibility considers these elements.

Students are evaluating the degree of change the policy and decisions have on the issues identified in the Rich Picture. As a consequence of selecting and implementing the policy solution do the issues in the Rich Picture disappear totally, partially or not all? Evaluation of policy, is not an objective process but subjective given the human activity systems of tourism and decision making (Yeoman, 2012a). I do not tend to use staging 5a and 5b (Checkland, 1981) in my teaching because of the issue of time constraints (Table VII).

\section{Stage 6: systemically desirable and culturally feasible}

Power and politics are a central feature of stakeholders and the successful implementation of the tourism policy. Stage 6 is of primary importance in order to initiate a debate with stakeholders and actors to generate an understanding about possible changes that might occur within the problem situation, fundamentally identifying the risks associated with the conceptual model in Stage 5. Systemically refers to something that is spread throughout, system-wide, affecting a group or system such as a stakeholders, economy or society. Here, it is important to understand the implications of the conceptual model or policy solution.

\section{Figure 6 Examples of tourism policy instruments by government involvement}

\section{Table VI Teaching task: policy solution(s)}

Hicks (1994) establishes that the conceptual model describes the activities of human activity systems, and so activities are the entities which form the components of the conceptual framework. In TOUR301 the conceptual model is the policy solution which is built up at Stage 3 consisting of the vision and guiding principle. Those elements are supplemented with five key decisions

Tutorial activity

Using a A4 sheet of paper, ask the students to draw a circle in the centre where they will write vision and guiding principle established in stage three. Ask the students then to draw five circles to surround the central circle. Each one of these circles represents a decision. Decisions are selected based upon the political ideology and the context of the problem (see Figure 6)

Decisions are selected from a range of options listed in Table $V$

It is suggested students construct two opposing conceptual models based upon opposite or different political ideologies, thus allowing the students to learn different policy perspectives 
Students are evaluating the degree of change the policy solution has on the issues identified in the Rich Picture. As a consequence of selecting and implementing the policy solution do the issues in the rich disappear totally, partially or not all?

Tutorial activity

Students should have completed two policy solutions in order that they can compare and contrast solutions. This means students are evaluating for recommendation

Ask the students to construct an evaluation matrix for each policy solution listing impact against issues. Score each decision/issue using with Issue totally eliminated -2

Issue partially eliminated -1

No impact or not applicable - 0

Eco Paradise

Decision 1: strengthen Resource Management Act in order to balance environment with economics

Decision 2: penalise bad environmental practice

Totally eliminated. Strengthens brand communication (2)

Issue 1: brand
reputation is tarnished

Issue 2: growing market Partially eliminated. Addresses a potential issue of over

from Asia

Issue 3, etc.

The policy solution with the highest score is perceived as the most effective and therefore recommended to be put forward at Stage 6.

However, other evaluation criteria can be used, that is, identifying the most effective decision, ranking decisions in order of importance, etc.

This recommendation can be communicated in the following manner

"[...] policy solution [...] is recommended as the impact is [...]" (in not more than 40 words)
All policies have a political flavour and they match or clash with stakeholder's value and belief systems. The more the policy matches stakeholders values, the greater the degree of support but if the policy clashes with stakeholders values, those stakeholders will act as an opposition to the implementation of the policy. Lubell (2003) proposed a system of stakeholder evaluation through understanding the correlation between beliefs and policy effectiveness, fundamentally all the virtues that Checkland (1981) argues in Stage 6 of SSM. At the centre of feasibility are the political values and beliefs of stakeholders. For example, The Tourism Industry Association of New Zealand (www.tianz.org.nz) is membership organisation of tourism businesses, therefore its value and belief system is shaped by capitalist systems of producing goods and services for profit thus policy focusses on entrepreneurship, laissez faire, creating a competitive environment and reducing bureaucracy (Wallace and Riley, 2015). Culturally feasibility also includes "destination values", for example, the debate about Gambling (Yeoman, 2012b) in many countries is of importance. In New Zealand, casinos are allowed in Auckland, Dunedin, Christchurch, Hamilton and Queenstown whereas in Wellington the local authority rejected the idea of casino development in the city after consultation with the residents (Doorne, 1998). Sex tourism, lapdancing and prostitution are contentious issues in many parts of the world but in New Zealand, prostitution is decriminalised. Whereas in most of the USA (except Nevada), prostitution is illegal on moral and criminal grounds.

Different countries have different values and belief systems. In Saudi Arabia, the consumption and selling of alcohol is illegal and enforced with strict penalties based upon an Islamic value and belief system, whereas in Qatar although a Muslim country, alcohol consumption is accessible in luxurious hotels.

Desirability represents the value proposition of the policy solution. Does the policy enhance or create value for the tourism industry? What is the central benefit of the proposed policy to the tourism industry? Is the policy worth it? (Table VIII).

\section{Stage 7: implementation}

A key activity of any democratically elected government is to deliver on its promise, hence why the implementation stage is important in the policy cycle. Implementation is the process in which policy ideas and plans are translated into practice. The challenge for policy makers is to develop effective implementation methods for the delivery of policy (Dredge and Jenkins, 2006). The role 
Students are evaluating the degree of change desirability and feasibility of the conceptual model or policy solution at this stage, fundamentally a stakeholder analysis

Tutorial activity

Students should identity three stakeholders related to the problem situation. A stakeholder is defined as an interested party which has presentation. Representation means the stakeholder is a real business or organisation rather just a group. A group, such as international tourists or local council are not real stakeholders. But the Tourism Export Council of New Zealand (www.tourismexportcouncil.org.nz) is a real organisation representing inbound tour operators or Auckland City Council (www.aucklandcouncil.govt.nz) represents the population of Auckland. These organisations have values and beliefs and influence that can be identified

For each stakeholder, complete through research the stakeholder evaluation matrix (see below) in order to identify behaviours, influence and impact of the policy solution. Evaluations can be made by identifying organisational policies, mission statements, research papers and other published material

\begin{tabular}{|c|c|c|c|c|c|}
\hline Stakeholder & Core values and beliefs & Interest in the issue & Influence/power & $\begin{array}{l}\text { Positional } \\
\text { behaviour }\end{array}$ & $\begin{array}{l}\text { Impact of the } \\
\text { issue on "them }\end{array}$ \\
\hline $\begin{array}{l}\text { John Key - Prime } \\
\text { Minister }\end{array}$ & $\begin{array}{l}\text { Capitalist economic } \\
\text { growth }\end{array}$ & Minister of Tourism & Extensive & $\begin{array}{l}\text { Manipulation and } \\
\text { power }\end{array}$ & Political issue \\
\hline Accor Hotels & $\begin{array}{l}\text { Shareholder value of } \\
\text { profit and sustainable } \\
\text { growth }\end{array}$ & $\begin{array}{l}\text { Largest hotel provider } \\
\text { in New Zealand }\end{array}$ & $\begin{array}{l}\text { Substantive in the business } \\
\text { community as the largest hotel } \\
\text { chain in New Zealand }\end{array}$ & Advocacy & High \\
\hline $\begin{array}{l}\text { Environmental } \\
\text { Defence } \\
\text { Association (www. } \\
\text { eds.org.nz/), etc. }\end{array}$ & $\begin{array}{l}\text { Protecting New } \\
\text { Zealand's environment } \\
\text { through advocacy }\end{array}$ & $\begin{array}{l}\text { Organisational value to } \\
\text { campaign for a better } \\
\text { environment }\end{array}$ & Scientific expertise & $\begin{array}{l}\text { Disruptive, scientific } \\
\text { evidence, } \\
\text { advocacy, lobbying }\end{array}$ & Moderate \\
\hline
\end{tabular}

The risk estimate matrix is also a useful tool to identify likelihood, impact and consequences of the conceptual model or policy solution. See: www.brighthubpm.com/risk-management/88566-tool-for-assessing-project-risk/

Using this question, "what is the most desirable aspect of the adopting the conceptual model or policy solution for the tourism industry?" identify the most desirable feature of the policy solution

Finally, if the policy solution is deemed not acceptable, revisit Stage 5 and select an alternative conceptual model. Iteration is a central feature of SMM

of implementation is about managing the change process in order that the policy is effectively implemented. This includes mechanisms of review. The core features of implementation include the following:

- Change management: in order to implement policy, change management requires the transitioning of individual, teams and organisations to that policy future. One of the core dimensions of the change management is understanding stakeholders and actors behavioural position as identified in Stage 6 and deploying appropriate strategies in order to minimise resistance to change.

- Project management and scheduling: the role of policy makers and planners is to carefully plan, organise and control the implementation process ensuring that policy is effectively implemented. In order to achieve this, project management requires the co-ordination of resources through use of GNATT charts, financial plans, critical path analysis, goals and targets, etc.

- Co-ordination: governments rarely act without repercussion for other governments and nongovernment departments. The interconnections of policy is mainstream of government, especially tourism. In New Zealand, direct tourism strategy is limited to marketing through Tourism New Zealand (Yeoman et al., 2014) but interconnectiveness is evident through other government ministries, departments and Crown agencies. For example, conservation is the responsibility of the Department of Conservation as the department is such a big player in tourism whether it is the Great Walks of New Zealand (www.doc.govt.nz/parks-andrecreation/things-to-do/walking-and-tramping/great-walks/) or the concessions paid by tourism businesses to operate in national parks (www.doc.govt.nz/get-involved/apply-forpermits/businesses/). Co-ordination is an important role within tourism policy implementation given the complexity and interrelationships of policy decisions. Often, policy solutions may seem appropriate in one government ministry but be in conflict in another. Co-ordination ensures government policies work in harmony with each other.

- Review: policy solutions usually have goals and targets as part of an implementation plan. These goals represent criteria for success. An implementation plan incorporates mechanisms for the review of policy at a future date in order to evaluate success (Table IX). 
Students are designing an implementation plan for the successful delivery of the policy solution

Tutorial activity

Identify who is responsible for the implementation stage that is, government department

Select an implementation committee with responsibility for implementation inclusive of stakeholders and government departments Draw up terms of reference for the implementation committee of not more than six bullet points

Identify three criteria for success of the policy solutions in the form of goals which are S (Specific), M (Measurable), A (Attainable), R (Realistic) T and (Time Related). See: www.ci.azusa.ca.us/DocumentCenter/View/29524

In not more than 50 words that describes the fundamental benefit of the policy solution. Here, students are advocating the policy solution and why it should be implemented. Communication is a core strategy in minimising resistance to change

\section{Concluding lessons}

This paper "Keeping it Pure - A Pedagogical Case Study of Teaching Soft Systems Methodology in Scenario and Policy Analysis" contribution to tourism futures lies in documenting how I (lan Yeoman) teach scenario analysis through TOUR301. Thus making it explicit the how's, why's, when's and what's of teaching the future. The how's reflect the nature of the paper in how my teaching occurs, the why's are a reflection of Yeoman's teaching philosophy, the when's reflect the scheduling and adaption of the SSM processes. My way and the what's reflect the teaching content and exercises elaborated in this paper. TOUR301 is regarded as a highly quality tourism course according to Victoria University student survey's with the course being rated 1.4 with 1 being excellent and 5 being poor for the survey question "overall, I would rate the quality of this course as [...]" Over the last five years, I have incrementally improved the course based upon student feedback and pedological developments. Therefore, in order to conclude, I reflect upon the teaching and learning of TOUR301 through five learning lessons for others who may seek to adopt, apply or listen.

\section{Lesson 1: facilitating a learning environment}

TOUR301 is a representation of my teaching philosophy of "authenticity - problem-based learning - negotiation". Providing students with a real problem, thus authentic. A problem that is unclear in several dimensions so students have to negotiate their understanding of the problem situation. A problem-based learning approach which requires students to identify a problem, analyse the situation, generating options and evaluation through to implementing a solution. My approach to teaching TOUR301 defines the teacher as a facilitator providing the students with a structure through SSM as the framework. Through facilitation, my approach is that of a supporter, director, providing guidelines and creating dialogue for learning. As documented in this paper, the framework of SSM allows the students to construct their own learning through negotiation and problem solving. As a facilitator I engage with students rather than lecturing to students. Facilitation is about guiding, setting direction and providing feedback. Students take their own responsibility for learning and working with others in order to achieve an outcome. I recognise the importance of a simulating environment of reality in which students self-learn through problem solving, knowledge sharing, social networks and interactions which allows reflection and actionbased learning as far as possible. SSM allows students a degree of abstraction through Rich Pictures and experimentation through conceptual models (policy solutions). SSM deals with ambiguous problems which allows the students to negotiate their understanding of the problem. This includes negotiation with students, as they often work in small groups in tutorials. I act as a "clarifier" where problem situations are not understood or need clarification.

\section{Lesson 2: the impact of visual thinking}

The medium of SSM and my approach to learning is visual thinking through use of Rich Pictures and conceptual models (policy solutions) to facilitate students understanding. The use of pictures refers to Haber's (1970) research about radiant thinking in which individuals have a recognition accuracy of images of between 85 and 98 per cent, hence the well-known quote "a picture is worth a thousand words". The theory behind Checkland (1981) as Avison et al. (1992) documents the use of SSM as a learning tool is powerful enabling students to quickly understand problems, see connectivity and the whole picture. 
Students said in feedback (Victoria University of Wellington, 2015):

Interest in the subject due to creativity of pictures [...]

Drawing rich pictures helped develop deeper understanding [...].

Mind maps and diagrams was a very simulating way to learn. Encouraged participation, helped to understand the course.

Rich pictures, pure magic.

Thus, being visual allows students to engage with the problem in a holistic manner, allowing them to see connections instantly. However, it is noted some students do not like Rich Pictures as they say "they cannot draw" (Victoria University of Wellington, 2015). To overcome this barrier, it is a matter of supporting students in getting started, as explained in the paper. Pictures and cartoons are supported by bubble clouds with commentary.

\section{Lesson 3: political theory}

One of common issues for students is that as tourism students they are not exposed to political theory or "they are not politics students" (Victoria University of Wellington, 2015) In student feedback about "which topics would you have liked to have spent more time on", comments included:

Different political theories

Political ideology

If I wanted to study politics, I would have taken a bloody degree in the topic.

We have learned a lot and the course is really structured well from a learning perspective, but I felt I didn't understand or couldn't apply political ideologies which is at the centre of the policy solutions stage.

The issue of political ideology is at the centre of TOUR301. I undertake two lectures on different political philosophy's, supportive readings and builds in feedback mechanisms for students in which they test policy solutions. The criticism is about the balance between declarative and procedural learning. My teaching philosophy of authentic and problem-based learning is biased towards procedural knowledge, how to do something rather than factual understanding of politics. I accept this point and has continuously incrementally improved the course year on year.

\section{Lesson 4: the importance of incremental learning}

As the use of SSM was a new skill and approach to learning for tourism students, the teaching and learning of SSM adopted the principles of scaffolding which originates in Lev Vygotsky's sociocultural theory and his concept of zone of proximal development (Raymond, 2000, p. 176).

The zone of proximal development is the distance between what children can do themselves and the next learning that they can be helped to achieve with competent assistance.

Scaffolds in TOUR301 are deployed to help student's breakdown the complexity and daunting tasks of the process. Here I articulate precisely the activities students must undertake and complete each week before moving forward through the various stages of the SSM process. For example, I recommend students complete a rich picture which clearly defines the problem situation, explicitly communicates the features of the rich picture to others through a key system, etc. Through making the stages of the SSM process explicit or suggesting hints, the students can sense achievement in the learning process. TOUR301 is taught over four weeks in the classroom using a case study (see the Appendix). Each week students prepare for tutorials with a clear understanding that previous tutorial tasks have to be completed before undertaking the next activities, thus interlinking tutorial activity in a continuum.

\section{Lesson 5: problem-based learning and international students}

A minority of international students struggle with a problem-based learning approach (Huang, 2007), in particular Chinese students prefer passive teaching methods such as lectures and demonstration and a Confucian-derived preference of rote learning. Chinese students maybe more concrete and pragmatic in evaluating ideas than Western students, and suffer from a lack of creativity as well as 
being less likely to explore new directions to which they are unaccustomed. Problem-based learning is an approach to learning that enables students to understand their own situations and frameworks so that they are able to perceive how to they learn. As TOUR301 is a level three paper, in which learning is focussed on critical thinking. Students will have accumulated knowledge about tourism (level 1) and applied management (level 2) through the structure of the Bachelor of Tourism Management degree. Therefore a problem-based approach to learning is appropriate for level 3 courses. In order to support students confidence in using a problem-based learning, a number of pedological actions where initiated. First, since 2013, a draft report was included in the tutorial and workshop schedule in which all student groups received feedback from me before submission of assignments for grading. Second, in the first six weeks of the course, emphasis is placed on declarative knowledge in order that students can construct a political understanding of tourism policy. Third, with the support of student learning (www.victoria.ac.nz/st_services/slss/) individual students not coping with a problem-based approach to learning attend additional workshops in the topic and are assigned a learning counsellor.

\section{References}

Avison, D., Golder, P. and Shah, H. (1992), "Towards an SSM toolkit: a rich picture diagramming”, European Journal of Information Systems, Vol. 1 No. 4, pp. 397-408.

Blanke, J. and Chiesa, T. (2014), "The travel \& tourism competitiveness report 2013”, World Economic Forum, available at: http://reports.weforum.org/travel-and-tourism-competitiveness-report-2013/\#1/4 (accessed 10 November 2014).

Checkland, P. (1981), Systems Thinking: Systems Practice, Wiley \& Sons, Chichester.

Checkland, P. and Scholes, P. (1990), Soft Systems in Action, Wiley \& Sons, Chichester.

Doorne, S. (1998), "Power, participation and perception: an insider's perspective on the politics of Wellington's Waterfront redevelopment", Current Issues in Tourism, Vol. 1 No. 2, pp. 129-66.

Dredge, D. and Jenkins, J. (2006), Tourism Planning and Policy, John Wiley \& Sons, Melbourne.

Haber, R. (1970), "How we remember what we see", American Scientific, Vol. 222 No. 5, pp. 104-12, available at: www.scientificamerican.com/article/how-we-remember-what-we-see/ (accessed 31 March 2016).

Heywood, M. (2013), Politics, Palgrave, Basingstoke.

Hicks, M. (1994), Problem Solving and Decision Making, Chapman \& Hall, Basingstoke.

Howe, C. (2012), "Beyond Rio? Paradise lost", Report for the World Wildlife Fund, Wellington, available at: www.org.nz/?8941/Paradise-lost-New-report-shows-20-years-of-environmental-inaction-threatensNZsnatural-heritage (accessed 1 December 2012).

Huang, R. (2007), "Chinese international students perception of problem based learning experience", Journal of Hospitality, Leisure, Sport and Tourism Education, Vol. 4 No. 2, pp. 36-44.

Kakabadse, N. (2005), "Visioning the pathway: a leadership process model", European Management Journal, Vol. 23 No. 2, pp. 237-46.

Kirk, D. (1995), "Hard and soft systems: a common paradigm for operations management", International Journal of Contemporary Hospitality Management, Vol. 7 No. 5, pp. 13-16.

Lubell, M. (2003), "Collaborative institutions, belief-systems and perceived policy effectiveness", Political Research Quarterly, Vol. 53 No. 3, pp. 309-23.

McClure, M. (2004), The Wonder Country: Making New Zealand Tourism, Auckland University Press, Auckland.

Mingers, J. (2000), "An idea ahead of its time: the history and development of soft systems methodology", Systemic Practice and Action Research, Vol. 13 No. 6, pp. 733-55.

Open University (2014), Rich Pictures, Open University, Milton Keynes, available at: http://systems.open.ac. uk/materials/T552/pages/rich/richAppendix.html (accessed 20 November 2014).

Pearce, D. (2012), Frameworks for Tourism Research, Cabi, Wallingford, CT.

Raymond, E. (2000), Learners with Mild Disabilities, Allyn \& Bacon, Needham Heights, MA.

Robertson, M. and Yeoman, I. (2014), "Signals and signposts of the future: literary festival consumption in 2050", Tourism Recreation Research, Vol. 39 No. 3, pp. 321-42. 
Rutherford, H. (2011), Kiwi Tourism must Change: English, available at: www.stuff.co.nz/business/industries/ 5281270/Kiwi-tourism-must-change-English (accessed 20 August 2011).

van der Heijden, K., Bradfield, R., Burt, G., Cairns, G. and Wright, G. (2002), The Sixth Sense: Accelerating Organisational Learning with Scenarios, Wiley, Chichester.

Victoria University of Wellington (2015), "Student evaluations - TOUR301", available at: www.cad.vuw.ac.nz/ feedback/feedback_display.php (accessed 31 March 2015).

Wallace, S. and Riley, S. (2015), "Tourism 2025: an industry perspective”, Journal of Tourism Futures, Vol. 1 No. 1, pp. 53-7.

Yeoman, I. (2004a), "The development of soft OR conceptual map of facilitation", PhD thesis, Napier University, Edinburgh.

Yeoman, I. (2004b), "Scottish tourism: scenarios and vision", Journal of Vacation Marketing, Vol. 11 No. 1, pp. 67-83.

Yeoman, I. (2012a), "Authentic learning: my reflective journey with postgraduates", Journal of Teaching in Travel \& Tourism, Vol. 12 No. 3, pp. 295-311.

Yeoman, I. (2012b), 2050: Tomorrows Tourism, Channelview, Bristol.

Yeoman, I. and McMahon-Beattie, U. (2014), "New Zealand tourism: which direction does it take?", Tourism Recreation Research, Vol. 39 No. 3, pp. 415-35.

Yeoman, I., Black, L. and Lennon, J.J. (2005), "Foot and mouth disease: a scenario of reoccurrence for Scotland's tourism industry", Journal of Vacation Marketing, Vol. 11 No. 2, pp. 179-90.

Yeoman, I., Lennon, J.J., Blake, A. and Galt, M. (2006), "Oil depletion: what does this mean for Scottish tourism?", Tourism Management, Vol. 28 No. 5, pp. 1354-65.

Yeoman, I., Palomino-Schalscha, M. and McMahon-Beattie, U. (2014), "Keeping it pure: could New Zealand be an Eco Paradise?", Journal of Tourism Futures, Vol. 1 No. 1, pp. 20-36.

\section{Further reading}

Huang, R. (2005), "Practice paper Chinese international students' perceptions of the problem-based learning experience", Journal of Hospitality, Leisure, Sport and Tourism Education, Vol. 4, No. 2, pp. 36-43, available at: www.hlst.heacademy.ac.uk/johlste

Yeoman, I. (2008), Tomorrows Tourist, Elsevier, Oxford.

\section{Appendix. New Zealand: is it an Eco Paradise?}

\section{New Zealand tourism: an Eco Paradise}

New Zealand could be an Eco Paradise some would say. Its "natural unspoiled beauty" has been the main reason for visiting the country since the latter half of the nineteenth century. The very first significant attractions were hot springs and the magnificent pink and white terraces - later destroyed in 1886 by a volcanic eruption - around Rotorua. By the 1890s, tourists enjoyed spas and thermal areas around the country, went tramping in the Milford Sounds, Mt Cook and Tasman Glaciers, visited Waitomo glow worm caves, were taken by steamer on the Whanganui river and engaged in sporting activities including hunting and fishing. Today, in general, tourists consider that the main highlights of their visits to New Zealand are its beautiful landscapes, its people, or visiting family. Indeed, a survey conducted in 2008 demonstrated that natural attractions are the main reason why international tourists visit the country. It is not surprising that "100\% Pure New Zealand" has become this country's destination brand built on previous campaigns as "Scenic Wonderland".

\section{In economic terms}

In New Zealand, tourism is a key contributor the country's economy and employment. In 2013, tourism generated 3.7 per cent of direct contribution to New Zealand's GDP, amounting to $\$ 7.3$ billion, while indirect value added of industries supporting tourism generated an additional $\$ 9.8$ billion to tourism. In addition, a total of 110,800 full-time equivalent employees have been employed within the tourism industry, accounting for 4.9 per cent of New Zealand's total 
employment. Tourism is one of New Zealand's top export earners, contributing 5.7 per cent of the country's total exports on goods and services. These statistics illustrates the key role tourism plays within the wider New Zealand's economy. However, in light of global economic turbulence, environmental issues, emerging markets and changing consumer attitudes, managing sustainability is critical to the continual growth of the industry.

\section{$100 \%$ Pure New Zealand}

Considered by some as one component of a broader national branding strategy to project the country as a unique and innovative place to visit, live and invest in, the "100\% Pure New Zealand" campaign is considered to be a natural extension and elegant expression for the clean and green space that New Zealand had long occupied in the minds of global consumers. Thus it helps construct a national image aligned with New Zealand resources, consumer demands and expectations, and that is also adaptable to target-specific segments of the diverse global market. Portraying New Zealand as a young, beautiful and clean country, the idea of "purity" can be mainly applied not only to the natural environment, represented as pristine, undiluted and de-humanised, but also to other elements such as Māori culture and hospitality, and locally produced food and wine.

\section{New Zealand today}

So, is New Zealand An Eco Paradise? This is Alberto's story on this day, 14 November 2014, aged 34. Alberto is a third generation Italian who lives in Auckland, New Zealand and is a tourism professor. This is how he sees the present state of tourism in New Zealand.

The landscape, the environment and climate change are the key issues of the day. Reading the newspapers reminds us about resource shortages. In Australia, it is water. In Africa, it is food, and in Asia it is floods. The world cannot agree on what to do. Kyoto is no more. America does not trust Africa and will not share solutions with China. Over a billion people in the world took an international holiday in 2015 this is due in the main through population growth and the expanding middle classes of Asia. I love New Zealand for its natural landscapes and authentic views. New Zealand was the first country in the world to have a Ministry of Tourism (called the Ministry of Tourism and Resorts in those days). It was Harry Wigley, who developed ski equipped aircraft for the glaciers in 1995 and it was AJ Hackett who brought bungy jumping to Queenstown in the 1980s. Today, I see a tourism industry which is everyone's business which offers a diversity of products and experiences. But the main reason for tourism travel today to New Zealand, is still the same as it was in the nineteenth century, the landscapes. At that time, the first tourists were well to do members of society, mainly from the Empire but it was Thorpe Talbot's guide book for travellers to New Zealand published in 1872 on "Lakes and Hot Springs" which saw the beginnings of "package holidays" (McClure, 2004). They travelled on steam ships, which took four to seven weeks as compared to six months by sailing ships. Today, its 24 hours on an aeroplane.

Then as today, tourism was (and is):

Department of Tourist and Health Resorts soon discovered the diverse, fragmented nature of the tourist industry as it took on a range of activities from employing masseurs to running steamers and importing deer. It's major focus, however was on international tourists and their foreign currency, and on the few resorts they favoured (McClure, 2004, p. 2).

Government's intervention into tourism was characterised by the Thermal-Springs Act Districts Act of 1881 allowing the government to define and proclaim thermal districts. The aim of the act was not to preserve but to develop. As a consequence, the government obtained 4,000-5,000 acres of Lake Rotorua. Rotorua was proclaimed a township and the majority of government officials on its board (it was nationalised), developed it like a European resort with golf, casino's, Bath Pavilion, beach promenades and proclaimed a health resort where one "could take the waters".

Today, tourism faces many challenges. Its share of global tourism arrivals is 0.03 per cent, and on a world stage this country is a small player compared to those like India and China. Tourism is a significant contributor to New Zealand's export income. The country's tourism brand, " $100 \%$ Pure New Zealand", is recognised as one of the world's leading tourism brands and has served to influence other countries' tourism and national branding. 
Most recently, Ms McPherson (Yeoman et al., 2014) Deputy Secretary at the Ministry of Economic Development and New Zealand's highest-ranking tourism public servant has stated that tourism was at a flip point due to the turmoil of uncertainties whether this was the global financial crisis, changing markets, currency fluctuations or terrorism.

In a similar vein New Zealand's Finance Minister, the Hon Mr Bill English, warned that:

Traditional markets such as the US and UK can no longer be relied on for inbound tourism as over the next 10 to 15 years we will continue to see further concerns over government debt levels, including the possibility of another financial crisis unfolding in Europe (Rutherford, 2011).

As the Hon Bill English (Rutherford, 2011) further noted, this country has seen the reduced competitiveness of its dollar over the previous seven years with the New Zealand dollar giving strength against the major currencies. Indeed, the country saw solid growth in tourism up until 2004, but since then its average real effective exchange rate stabilised at quite a high level with a corresponding drop in visitor expenditures. Traditional markets such the UK and the USA have been and are diminishing in value, while Asian markets have been and are increasing, with many Asian visitors prepared to spend more. New Zealand is a long haul destination, with significant demands on energy/fuel for international travel. As the world is entering a period of peak oil, defined as the point in time when the maximum rate of global petroleum extraction is reached and after which the rate of production enters terminal decline. There is some stagnation, with New Zealand's tourism industry growing less quickly than some its international competitors in particular visitor arrivals, length of stay and expenditure are static or falling.

In the longer term, key demographic changes in traditional markets such as the UK, Japan and Germany could see significant changes in wealth per capita, which is one of the key drivers of propensity to travel. Significant changes in the application of technologies, the emergence of new consumer markets, New Zealand's forecasted fiscal deficits and climate change systems, and media and communications networks, has become increasingly sensitive to many factors, including economic downturn.

Given the political and economic importance of tourism with the Rt. Honourable John Key, both the Prime Minister and Minister of Tourism, the government and industry in partnership responded to these challenges, overseeing the development of a national framework (http:// tourism2025.org.nz/) based upon five themes. Namely, productivity growth, enhancing the visitor experience, informed research, grow air connections and focus on niche consumers. The response, on one hand, has been an industry on a voluntary basis where stakeholders have come together in a united voice to say "this is how we can contribute". At the same time, the New Zealand government has increased Tourism New Zealand budget from NZ\$83.8 to NZ\$113.4 m, for the financial years 2014 and 2015, increasing to NZ\$115.8 m in 2016 and 2017. This additional funding will allow Tourism New Zealand to remain in core markets, but develop a strategy and presence in emerging markets. This approach to the future, some would say is based upon a neo-liberal or mechanist perspective of business and economic.

But there are still environmental problems which bug me.

If New Zealand is an ecotourism destination as Tourism New Zealand says, then why does it have problems such as:

- Increasingly polluted lakes and rivers, with 43 per cent of monitored lakes in New Zealand now classed as polluted with an estimated 18,000-34,000 people annually catching waterborne diseases.

- More than 60 per cent of native freshwater fish as well as the only freshwater crayfish and mussel species are now threatened with extinction.

- Seven of New Zealand's ten official "indicator species" for measuring biodiversity status are threatened. The Kokako, for example, has suffered a 90 per cent contraction in its range since the 1970s.

- Iconic species such as Maui's dolphins and New Zealand sea lions are listed as "nationally critical". Only an estimated 55 Maui's over the age of one year old remain and New Zealand sea lion pup numbers have halved over the past 12 years at their main breeding area in the Auckland Islands. 
- Almost two-thirds of New Zealand's seabird species are listed as threatened with extinction. The main threats to seabirds are predation by introduced mammals, fishing methods and human disturbance.

- New Zealand's gross emissions have risen by 20 per cent since 1992, due to increased pollution from energy, transport, agriculture and industry sectors. Even with our weakened Emissions Trading Scheme, emissions are projected to continue to rise.

I think, "100\% Pure New Zealand" is a brand with problems because of the country's environmental issues. These issues where highlighted in a report, Beyond Rio, by the global conversation organisation World Wildlife Fund (Howe, 2012) stating that: "Aotearoa, the land of the long white cloud, is now a land of polluted rivers and lakes, rising greenhouse gas emissions, pressured marine ecosystems and disappearing bird and mammal species".

But maybe I am just worried about nothing. Maybe it's just the press trying to portray a bad story. I recently read the Travel and Tourism Competitiveness Report (Blanke and Chiesa, 2014, p. 37) and found:

The importance of the natural environment for providing an attractive location for tourism cannot be overstated, and it is clear that policies and factors enhancing environmental sustainability are crucial for ensuring that a country will continue to be an attractive destination going into the future. In this pillar we measure the stringency of the government's environmental regulations in each country as well as the extent to which they are actually enforced. Given the environmental impacts that tourism itself can sometimes bring about, we also take into account the extent to which governments prioritize the sustainable development of the travel and tourism industry in their respective economies. In addition to policy inputs, this pillar includes some of the related environmental outputs, including carbon dioxide emissions and the percentage of endangered species in the country.

I know, The World Economic Forum's Travel and Tourism Global Economic Competitiveness report positions Sweden, Switzerland and Finland as the top three destinations for environmental sustainability, as these countries are characterised by environmental legislation that is both stringent and well-enforced. I see New Zealand is ranked 22nd in the world out of 140 countries. Areas of concern or poor performance are carbon dioxide emission (104/140) and threatened specifies (139/140). The country continues to benefit from its rich natural resources, with a number of World Heritage natural sites and a pristine natural environment protected by strong and well-enforced environmental legislation (9/140). Overall, the industries strategy and commitment to sustainability is world leading (2/140). The quality of natural environment scores 3/140 and commitment to protect the marine environment 3/140. Hence the World Economic Forum paints a balanced viewpoint regarding New Zealand commitment and position on the environment from a country and tourism perspective.

So, what are the issues, problems and directions forward for New Zealand tourism?

Alberto

\section{About the authors}

Dr lan Yeoman is an Associate Professor of Tourism Futures at the Victoria University of Wellington, New Zealand and an Visiting Professor at the European Tourism Futures Institute, The Netherlands. He is recognised as a Leading Authority on tourism futures, an Author of 17 books and over 100 research papers. lan Yeoman is the corresponding author and can be contacted at: ian.yeoman@vuw.ac.nz

Professor Una McMahon-Beattie of Head of the Hospitality and Tourism Management Department at the Ulster University, UK. She has contributed and co-authored a wide range of papers in consumer behaviour, tourism futures and revenue management.

Carol Wheatley is an MBA Graduate of the Victoria University of Wellington, New Zealand and is working on a number of tourism futures projects.

For instructions on how to order reprints of this article, please visit our website:

www.emeraldgrouppublishing.com/licensing/reprints.htm

Or contact us for further details: permissions@emeraldinsight.com 